University of Nebraska - Lincoln

DigitalCommons@University of Nebraska - Lincoln

Agronomy \& Horticulture -- Faculty Publications

Agronomy and Horticulture Department

$7-2013$

\title{
Rate of Shattercane $\times$ Sorghum Hybridization In Situ
}

Jared J. Schmidt

University of Nebraska-Lincoln

Jeffrey F. Pedersen

USDA-ARS, jpedersen1@unl.edu

Mark L. Bernards

Western Illinois University

John L. Lindquist

University of Nebraska-Lincoln, jlindquist1@unl.edu

Follow this and additional works at: https://digitalcommons.unl.edu/agronomyfacpub

Part of the Agricultural Science Commons, Agriculture Commons, Agronomy and Crop Sciences Commons, Botany Commons, Horticulture Commons, Other Plant Sciences Commons, and the Plant Biology Commons

Schmidt, Jared J.; Pedersen, Jeffrey F.; Bernards, Mark L.; and Lindquist, John L., "Rate of Shattercane $\times$ Sorghum Hybridization In Situ" (2013). Agronomy \& Horticulture -- Faculty Publications. 1036. https://digitalcommons.unl.edu/agronomyfacpub/1036

This Article is brought to you for free and open access by the Agronomy and Horticulture Department at DigitalCommons@University of Nebraska - Lincoln. It has been accepted for inclusion in Agronomy \& Horticulture -Faculty Publications by an authorized administrator of DigitalCommons@University of Nebraska - Lincoln. 


\title{
Rate of Shattercane $\times$ Sorghum Hybridization In Situ
}

\author{
Jared J. Schmidt, Jeffrey F. Pedersen, Mark L. Bernards, and John L. Lindquist`
}

\begin{abstract}
Cultivated sorghum [Sorghum bicolor (L.) Moench subsp. bicolor] can interbreed with a feral weedy relative shattercane $[S$. bicolor nothosubsp. drummondii (Steud.) de Wet ex Davidse]. Traits introduced from cultivated sorghum could contribute to the invasiveness of a shattercane population. An experiment was conducted to determine the potential for pollenmediated gene flow from grain sorghum to shattercane. Shattercane with juicy midrib $(d d)$ was planted in soybean [Glycine max (L.) Merr.] fields during $2 \mathrm{yr}$ in concentric arcs at varying distances from a 0.39 ha sorghum pollen source with dry midrib $(D D)$. The arcs were placed so that prevailing winds would carry sorghum pollen to the shattercane. Seven hundred twenty seeds from each of over 300 shattercane panicles in anthesis during sorghum pollen shed each year were collected. Progeny were evaluated by phenotype to determine rate of hybridization. Hybridization averaged $3.6 \%$ within the source in 2008 and $16.0 \%$ in 2009 and declined as distance increased. Hybridization as high as $2.6 \%$ for an individual panicle was measured at the farthest distance evaluated $(200 \mathrm{~m})$. Wind direction and speed were also measured and their product affected hybridization rate for all pollination periods. Results indicate that genes from cultivated sorghum will likely be introduced into shattercane populations at distances of at least $200 \mathrm{~m}$ and that rate of hybridization is dependent on weather factors such as wind. Source size is also important in determining hybridization rate but was not studied here.
\end{abstract}

J.J. Schmidt and J.L. Lindquist, Dep. of Agronomy and Horticulture, Univ. of Nebraska-Lincoln, 279 Plant Science Hall, Lincoln NE, 685830817; M.L. Bernards, School of Agriculture, Western Illinois Univ., Macomb, IL 61455; J.F. Pedersen, USDA-ARS, Grain, Forage, and Bioenergy Research Unit, Univ. of Nebraska-Lincoln, 130 Keim Hall, Lincoln, NE 68583-0739. Received 14 Sept. 2012. *Corresponding author (jlindquist1@unl.edu).

ENE FLOW can include the introduction of new alleles into a $\checkmark$ population or changing the frequency of existing alleles in a population. This can happen via seed dispersal and movement into a new population or by cross-pollination from an external source, which could be of the same or different but related species. There are many crops that have weedy or wild relatives and within those crop and weedy relative complexes, pollen-mediated crop-to-weed gene flow is not uncommon. For gene flow to occur, the species must be sexually compatible and flower synchronously (Arriola and Ellstrand, 1997; Baker, 1972; Spencer and Snow, 2001). Any novel traits that might be associated with crops, such as herbicide, pest, or disease resistance, could be introduced into weedy populations, which might result in a more successful and invasive weed population. If the hybrid or any introduced genes confer improved fitness over the weedy population, then success of the weed populations might increase. If the crop contains transgenes, then those transgenes and any associated traits can also be introduced into weedy populations. Whether transgenic technologies are involved or not, the consequences of gene flow from crops to weedy populations could be problematic because crop genes might replace genes in the weedy populations (Haygood et al., 2003; Andow and Zwahlen, 2006; Sahoo et al., 2011). Several instances of landscape-level pollen-mediated gene

Published in Crop Sci. 53:1677-1685 (2013)

doi: 10.2135/cropsci2012.09.0536

(C) Crop Science Society of America | 5585 Guilford Rd., Madison, WI 53711 USA

All rights reserved. No part of this periodical may be reproduced or transmitted in any form or by any means, electronic or mechanical, including photocopying, recording, or any information storage and retrieval system, without permission in writing from the publisher. Permission for printing and for reprinting the material contained herein has been obtained by the publisher. 
flow have occurred in species with a novel trait. Watrud et al. (2004) found that creeping bentgrass (Agrostis stolonifera L.) containing a transgenic trait for herbicide resistance outcrossed with nontransgenic grass and resulted in transgenic hybrids as far as $21 \mathrm{~km}$ away from the transgenic source. Rieger et al. (2002) also quantified landscape level movement of transgenic herbicide resistance genes in canola (Brassica napus L.) to other nearby canola fields.

Sorghum bicolor includes three subspecies, bicolor, verticilliflorum, and drummondii (Wiersema and Dahlberg, 2007). Grain sorghum belongs to the subspecies bicolor (Sorghum bicolor subsp. bicolor). Sorghum bicolor subsp. verticilliflorum (Steud.) de Wet ex Wiersema \& J. Dahlb. is generally thought to be a wild progenitor of cultivated sorghum. Sorghum bicolor nothosubsp. drummondii includes sudangrass, which is cultivated for forage, and shattercane, a feral, de-domesticated sorghum with many similarities to sudangrass and grain sorghum (Defelice, 2006). Grain sorghum and shattercane are both diploid $(2 n=20)$ and self-compatible as well as sexually compatible with each other and pollinated by wind and can produce hybrid offspring (Pedersen et al., 1998; Sahoo et al., 2011). With wind-pollinated species, wind direction and strength has an impact on hybridization, particularly at distance (Bannert and Stamp, 2007; Song et al., 2003; Okubo and Levin, 1989). Shattercane is a problematic weed in corn (Zea mays L.), sorghum, and soybean fields in the southern and central United States and can cause 85\% losses in yield and loss in quality due to seed contamination (ICRISAT, 2002; Hans and Johnson, 2002; Horak and Moshier, 1994).

There is considerable interest in developing sorghums that contain novel traits to improve grain quality, increase pest resistance, or confer resistance to herbicides. This can be accomplished through gene discovery in existing collections, induced mutations, or using transgenic technologies. For example, there are current efforts to improve the nutritional quality of grain sorghum using transgenic technologies (Grand Challenges in Global Health, 2003). In addition, grain sorghum varieties that are resistant to herbicides (primarily nicosulfuron [2-[(4,6-dimethoxypyrimidin2 -ylcarbamoyl)sulfamoyl]-N,N-dimethylnicotinamide] and rimsulfuron [1-(4,6-dimethoxypyrimidin-2-yl)-3-(3ethylsulfonyl-2-pyridylsulfonyl)urea]) are expected to be deployed commercially as early as 2014 . These traits were attained through traditional breeding by crossing weedy sorghum with resistance to acetolactate synthesis inhibitor herbicides discovered in farmers' fields with cultivated sorghum varieties (Rupp et al., 2009; Tesso et al., 2011; Tuinstra and Al-khatib, 2009, 2010, 2011). Sahoo et al. (2011) found that the fitness of the $F_{1}$ shattercane $\times$ sorghum hybrid with no novel traits had similar or improved fitness compared to the parents, indicating that introduced alleles conferring neutral or improved fitness would likely be maintained in subsequent populations.
Grain sorghum has been shown to outcross (crosspollinate) at a rate of 10 to $15 \%$ with other grain sorghum when planted side by side. Pollination by wind was observed at a frequency of $0.06 \%$ at a distance of $158 \mathrm{~m}$ from a pollen source (Ellstrand and Foster, 1983; Schmidt and Bothma, 2006). Sudangrass $(2 n=20)$ outcrosses with other sudangrass at a much higher rate (20-61\%) than grain sorghum, possibly because sudangrass has a more open and branching panicle than grain sorghum (Pedersen et al., 1998). Shattercane panicles are morphologically more similar to those of sudangrass panicles than grain sorghum. Therefore, we hypothesized that the rate of hybridization between grain sorghum and shattercane is closer to that reported for sudangrass. The object of this research was to determine the rate of shattercane $\times$ grain sorghum hybridization for synchronously flowering populations as it occurred in quasirealistic field conditions. We expected that rate of hybridization would decline with distance from the source population and that wind speed and direction will influence the rate of hybridization, especially at greater distances from the source.

\section{MATERIALS AND METHODS}

\section{Plant Materials}

Hybridization was quantified using a dominant phenotypic marker gene conferring a white (dry) $(D D)$ midrib. The sorghum used for the pollen source was a mixture of three separate sister lines with Tx623 (a common elite inbred sorghum line) background, all homozygous for the white midrib gene. Three lines were used because of limited availability of seed and because the lines differed slightly in the time to flowering and the inclusion of all three was thought to increase the possibility of synchronous flowering with shattercane. The shattercane line used was developed from a naturally occurring shattercane population collected near Lincoln, NE. Individuals from that population were selfed for six generations and selected for the recessive phenotype $(d d)$ conferring a juicy midrib, which appears green in color. The phenotype for the midrib locus is controlled by simple Mendelian genetics where the heterozygote occurring when the two lines are crossed $(D d)$ also confers the phenotype for the dominant white midrib (Pedersen et al., 1998). Figure 1 shows the two phenotypes.

\section{Hybridization Study}

A field experiment lasting $2 \mathrm{yr}$ was conducted twice, in $2008 / 2009$ (hereafter referred to as 2008) and 2009/2010 (referred to as 2009), at the University of Nebraska-Lincoln's Agronomy Farm located in northeast Lincoln, NE (4051'21.93" $\mathrm{N}, 96^{\circ} 36^{\prime} 23.20^{\prime \prime} \mathrm{W}$, and $354 \mathrm{~m}$ elevation). The experiment consisted of a population of grain sorghum as the pollen source and individual shattercane plants planted in groups along concentric arcs at varying distances from the source population. The experiment was set up such that prevailing southerly winds would carry pollen from the grain sorghum to receptive shattercane panicles. The entire experiment was isolated from any other sorghum by at least $600 \mathrm{~m}$ in any direction to prevent contamination from outside sources. 
The pollen source of grain sorghum was planted using a six-row planter in a $50 \mathrm{~m}$ radius half circle area. Soil type was Kennebec silt loam in 2008 and Crete silt loam in 2009. Rows were spaced $0.76 \mathrm{~m}$ apart and planted to a target density of 18 plants $\mathrm{m}^{-2}$ resulting in approximately 70,200 sorghum plants within the source population. Urea $\left(\mathrm{CO}\left(\mathrm{NH}_{2}\right)_{2}\right)$ fertilizer was applied to obtain a target yield of $5.6 \mathrm{Mg} \mathrm{ha}^{-1}$ using university recommendations (Wortmann et al., 2013). Weeds were controlled using a preemergent application of atrazine (1-chloro3-ethylamino-5-isopropylamino-2,4,6-triazine) at $1.68 \mathrm{~kg}$ $\mathrm{ha}^{-1}$ and by hand weeding. The source was planted on 3 July 2008 and 10 June 2009. The late planting date in 2008 was due to high rainfall in June that led to flooding in the field where the experiment was located. The stand of sorghum was less uniform and showed evidence of $\mathrm{N}$ stress in some spots in 2008, presumably because of the late planting date, which likely led to a decrease in the size of the root system, and leaching and denitrification from standing water that occurred before planting.

Shattercane seeds were sown in small groups (hills) of five seeds along concentric arcs spaced 1, 3, 5, 10, 20, 40, 60, 100, and $200 \mathrm{~m}$ from the edge of the sorghum source population. The hills were spaced $7 \mathrm{~m}$ apart from one another along the 100 and $200 \mathrm{~m}$ arcs and $5 \mathrm{~m}$ apart along all other arcs. Ten hills were also placed randomly within the source. The area around the source and where the hills were located as well as the area surrounding the experiment was planted to soybeans. The arcs encompassed 90 degrees of a circle and were centered directly north of the source population. To increase the chance of synchronous flowering between at least one shattercane plant for each hill and the source population, two shattercane seeds were sown approximately $30 \mathrm{~cm}$ apart from one another on the day the sorghum source was planted and at 3 and $6 \mathrm{~d}$ after source population planting. A $1.5-\mathrm{m}$ radius around each hill was kept weed and soybean free by hand weeding to minimize the effect of interspecific interference on shattercane flowering and to encourage the shattercane to tiller and produce more panicles. A 2-m alley was cut along the outer edge of the shattercane hills at the arcs spaced at $20 \mathrm{~m}$ and greater to facilitate access to the hills. The alley was cut before pollination but on the northern side of the hills about 5 $\mathrm{m}$ downwind from the shattercane so as to not interfere with the airborne pollen's northerly movement. Figure 2 shows an aerial photo of the experiment in 2009 with shattercane hills denoted.

\section{Sampling Strategy}

The source population was monitored to determine when flowering began. Sorghum flowering was considered to be underway when approximately $50 \%$ of the sorghum panicles within the source population were beginning to shed pollen. This occurred on 31 Aug. 2008 and 22 July 2009. On these dates, each shattercane hill was checked to determine if there was a shattercane panicle that was also beginning to flower. Panicles that were starting to pollinate were marked by attaching colored surveyors tape to the culms just below the panicle. Since not all shattercane had begun to pollinate, the hills were checked again several days later and if new shattercane panicles were beginning to pollinate, they were marked with a different color tape and were tracked separately as a new "flowering period." This was done three times in 2008 (31 August, 3 September, and 9 September) and twice in 2009 (22 July and 24 July). There were a total of 307 shattercane panicles in 2008

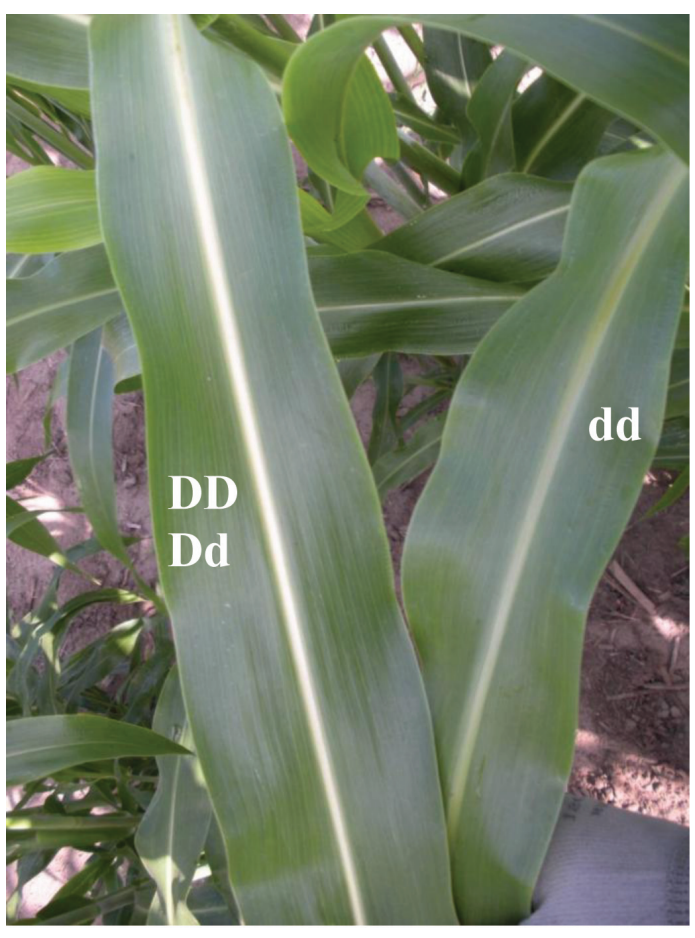

Figure 1. A photograph of the two phenotypes used to determine hybridization. On the left is the phenotype conferring a dry, white midrib. This occurred in both the homozygous sorghum and heterozygous hybrid. The left is the phenotype of the juicy, green midrib occurring in the homozygous shattercane only.

and 367 in 2009 that flowered in synchrony with the source (Table 1 lists the number of panicles at each distance). Shattercane panicles for each flowering period were tracked and an approximate end date for each flowering period was determined. This varied from 3 to $11 \mathrm{~d}$. The source continued to flower throughout all shattercane flowering periods.

Marked shattercane panicles were allowed to mature until they were close to shattering and then covered with pollination bags and stapled tightly near the base of the panicle to prevent any seeds that shattered from being lost. Mature shattercane panicles were harvested by clipping the stem below the bag and retaining the bagged panicle. Seeds from each panicle were threshed by hand and 720 seeds from each panicle were counted and separated into six envelopes containing 120 seeds each. These six replicates were planted in 7.62-m rows spaced $0.76 \mathrm{~m}$ apart using a cone planter on 15 June 2009 for the 2008 experiment and 25 June 2010 for the 2009 experiment. Panicles from each hill and flowering period were randomized within a replicate and plants in each 7.62-m row were counted and scored for the white midrib trait. For each panicle, total number of offspring and total number conferring the white midrib were determined by summing across replicates. Of the 720 seeds planted from each panicle, the mean number that emerged and grew large enough to score for the white midrib trait was 417 (SE \pm 5.3 ) in 2008 and 378 ( \pm 3.7 ) in 2009. Rate of hybridization was determined by dividing the number of plants with the white midrib trait by the total number present.

\section{Meteorological Data}

Wind direction, speed, and other weather conditions were measured and hourly averages were recorded using a weather station 


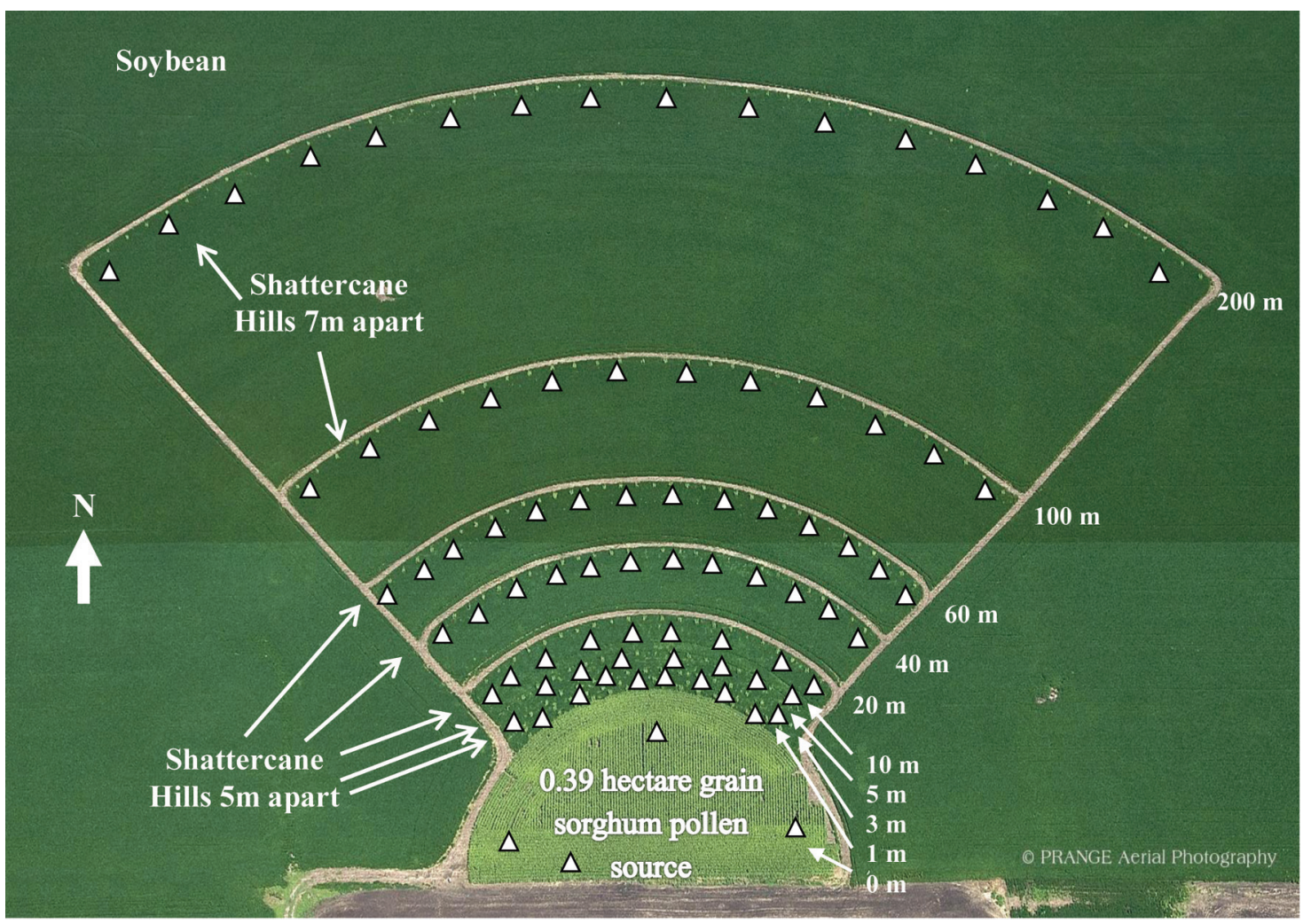

Figure 2. Aerial photograph of the 2009 experiment. The alleys adjacent to the shattercane hills along the concentric arcs $>20 \mathrm{~m}$ are evident. Location of shattercane hills are denoted with a $\triangle$ but are not to scale and do not show all hills; they just represent the general pattern.

Table 1. Effect of distance from edge the source on pollen-mediated gene flow from sorghum to shattercane in 2008 and 2009. For each panicle, 720 seeds were planted. From that, the mean number that emerged and grew large enough to score was 417 $( \pm S E=5.3)$ for 2008 and $378( \pm 3.7)$ for 2009 .

\begin{tabular}{|c|c|c|c|c|c|c|c|c|}
\hline \multirow[b]{2}{*}{ Distance } & \multicolumn{4}{|c|}{2008} & \multicolumn{4}{|c|}{2009} \\
\hline & $\begin{array}{l}\text { Mean } \\
\text { hybridization } \\
\text { rate (SE) }\end{array}$ & $\begin{array}{l}\text { Total no. } \\
\text { panicles } \\
\text { screened }\end{array}$ & $\begin{array}{l}\text { Percent panicles } \\
\text { with at least one } \\
\text { hybrid progeny }\end{array}$ & $\begin{array}{l}\text { Max. rate for } \\
\text { an individual } \\
\text { panicle }\end{array}$ & $\begin{array}{l}\text { Mean } \\
\text { hybridization } \\
\text { rate (SE) }\end{array}$ & $\begin{array}{l}\text { Total no. } \\
\text { panicles } \\
\text { screened }\end{array}$ & $\begin{array}{l}\text { Percent panicles } \\
\text { with at least one } \\
\text { hybrid progeny }\end{array}$ & $\begin{array}{c}\text { Max. rate for } \\
\text { an individual } \\
\text { panicle }\end{array}$ \\
\hline & $\%$ & & & 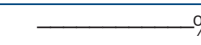 & 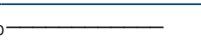 & & & $\%$ \\
\hline Within source & $3.61(0.76)$ & 10 & 100 & 8.47 & $16.02(1.31)$ & 20 & 100 & 26.68 \\
\hline $1 \mathrm{~m}$ & $2.98(0.49)$ & 23 & 100 & 10.2 & $9.70(1.28)$ & 24 & 100 & 24.17 \\
\hline $3 \mathrm{~m}$ & $2.23(0.36)$ & 25 & 100 & 7.78 & 7.07 (0.83) & 26 & 100 & 16.06 \\
\hline $5 \mathrm{~m}$ & $1.45(0.24)$ & 20 & 95 & 4.03 & $5.18(0.54)$ & 26 & 100 & 12.17 \\
\hline $10 \mathrm{~m}$ & $1.27(0.24)$ & 27 & 88 & 5.44 & $4.88(0.89)$ & 24 & 100 & 13.85 \\
\hline $20 \mathrm{~m}$ & $0.87(0.16)$ & 25 & 84 & 3.08 & $2.70(0.47)$ & 30 & 93 & 7.76 \\
\hline $40 \mathrm{~m}$ & $0.32^{\dagger}(0.05)^{\dagger}$ & 29 & 76 & $0.70^{+}$ & $1.89(0.36)$ & 37 & 95 & 9.3 \\
\hline $60 \mathrm{~m}$ & $0.33(0.07)$ & 29 & 66 & 1.52 & $1.45(0.23)$ & 57 & 88 & 8.33 \\
\hline $100 \mathrm{~m}$ & $0.16(0.10)$ & 46 & 20 & 4.66 & $0.90(0.16)$ & 50 & 78 & 4.96 \\
\hline $200 \mathrm{~m}$ & $0.09(0.04)$ & 73 & 12 & 2.41 & $0.34(0.07)$ & 73 & 41 & 2.56 \\
\hline
\end{tabular}

†Two outliers were omitted from these results because of unusually high levels of outcrossing likely due to protogyny.

placed within the source population. To determine the effect of wind direction and speed on hybridization, a wind value (wind run) was assigned to each hill for each flowering period. Wind run was determined by multiplying the average wind speed from 0700 to $1500 \mathrm{~h}$ in each of the primary 16 wind directions (N, NNE, NE, ENE, E, etc.) by the proportion of the time in which the wind blew in that direction for each flowering period. To determine which hills would be in the path of pollen blowing in each direction, artificial lines were drawn from both edges of the source and parallel to each wind direction. The entire experiment was given a $1-\mathrm{m} x, y$ coordinate grid where the origin $(0,0)$ was the midpoint of the southernmost edge of the source. Therefore, the most northerly point of the source was located at $(0,50)$ and the most northerly point of the farthest arc was at $(0,250)$. For each wind direction, two linear equations were derived representing a tangent from the edge of the source and extending in the direction of the specified wind direction. These equations created a $50 \mathrm{~m}$ wide path for each wind direction that started at the source and continued to the end of the last arc. To determine which hills would be included in each of the paths for each wind direction, we determined if the $x, y$ coordinate of each hill fell within the $50 \mathrm{~m}$ path for that 
wind direction. Then, for each hill, the wind run was summed for all paths that included the hill and a wind run value was given to each hill for each flowering period. Plants at greater distances from the source were included in fewer directional paths than those at closer distances. This approach attempts to address the issue of a relatively small source population by only including the shattercane that were in the direct, linear path of the pollen cloud.

\section{Data Analysis}

An empirical model of pollen-mediated gene flow from sorghum to shattercane was obtained by regressing the frequency of hybridization on distance from the source population using the negative exponential model: frequency of hybridization $=\alpha \times \exp [-\beta$ (distance) $]$ using the NLIN procedure in SAS 9.2 (SAS Institute, 2009). To assess the relative importance of wind speed and direction on rate of hybridization over distance, we included distance, wind run, and their interaction in an ANOVA using the GLM procedure in SAS 9.2. For these analyses, shattercane plants within the source population were assigned a distance value of $0.5 \mathrm{~m}$ since they were planted in the middle of the $0.76 \mathrm{~m}$ rows and were taller than the sorghum, which added additional separation. Each flowering period and year was analyzed separately.

\section{RESULTS AND DISCUSSION}

Hybridization was greater in 2009 than 2008 for all distances and flowering periods evaluated (Table 1). Several factors may have contributed to the difference in hybridization among years. The length of time of sorghum flowering within the source was greater in 2008 (22 d) than in 2009 (6 d), presumably because the weather was much cooler during flowering compared to 2009. The source was also less vigorous and less uniform in 2008 likely due to the flooding and later planting date. The longer flowering period and reduced stands in 2008 may have led to reduced pollen density in that year. Finally, results showed that wind was blowing from the southern directions a greater proportion of the time in 2009 (see Fig. 3 and 4), which may have resulted in pollen being carried to greater distances.

Forallflowering periods in both years, rate of hybridization declined exponentially as distance from the source increased. Table 1 shows the mean rate of hybridization at each distance for all flowering periods combined in each year as well as the maximum hybridization rate observed for an individual shattercane panicle, the total number of panicles found to be in flower at that distance, and the number evaluated that had at least one hybridized offspring. For both years there were panicles at all distances that contained hybridized offspring. In 2008 , hybrids occurred in $12 \%$ of the 73 shattercane panicles evaluated at $200 \mathrm{~m}$ and in over $65 \%$ of the 29 panicles at $60 \mathrm{~m}$, indicating that the risk of gene transfer is high if there are any synchronously flowering shattercane plants within $60 \mathrm{~m}$ of a sorghum population. In 2009, hybrids occurred in $41 \%$ of 73 flowering panicles evaluated at $200 \mathrm{~m}$ and $78 \%$ of 50 panicles evaluated at $100 \mathrm{~m}$ from the sorghum source, indicating that the probability of gene transfer remained high at $200 \mathrm{~m}$ from the edge of the source in 2009 and even higher at distances of $100 \mathrm{~m}$ and less. Our design was not sufficiently large to capture the distance where no hybridization occurred. Two panicles (both in the $40 \mathrm{~m}$ arc but from separate hills) that showed unusually high levels of hybridization (40\% [of 451 screened progeny] and 67\% [of 58 progeny]) in 2008 were not used in our analysis. We believe that these outliers occurred as a result of protogyny, where the plant becomes receptive before shedding its own pollen. The late planting in 2008 led to cooler temperatures during the later flowering. These panicles, unlike those that did not exhibit unusually high hybridization, did not produce 720 mature seeds for evaluation. If protogyny were to occur in weedy shattercane populations flowering synchronously with nearby grain sorghum, it would have major impact on localized gene flow.

The relationship between frequency of hybridization and distance from the edge of the source was compared among flowering periods by fitting a curve to the data from each period independently and comparing the confidence intervals for $\alpha$ and $\beta$. Table 2 shows the parameter estimates for each of the flowering periods. For the second flowering period of 2008, the data did not appear to fit the curve well because the confidence intervals for $\alpha$ and $\beta$ included 0 . This was perhaps because of the low number of observations in that period (39 panicles) compared to over 100 in all other periods. Figures 5 and 6 show the relationship between frequency of outcrossing and distance for all marking periods in 2008 and 2009. This empirical negative exponential model includes distance as the only predictive factor, and while the model is frequently used in the literature, other factors such as wind might influence hybridization frequency (Hanson et al., 2005; Song et al., 2003; Okubo and Levin, 1989; Bannert and Stamp, 2007).

Table 3 shows the results of the ANOVA using a multiple regression model, including both $\log$ (distance) and wind run (speed $\times$ proportion) to determine if they had an effect on frequency of hybridization. Distance is regressed here in a logarithmic fashion and wind run is also included to determine its impact; there was a significant $\log ($ distance $) \times$ wind run interaction for all flowering periods except the third period in 2008, indicating that wind speed and direction as well as distance from the pollen source have an impact on the rate of hybridization. The interaction between the two variables suggests that the importance of wind speed and direction varies with distance from the pollen source. Results indicate that wind speed and direction is more important for pollination at greater distances than for those shattercane plants growing just outside the pollen source. The importance of wind in cross-pollination can also be seen in Fig. 3 and 4, which show the wind trends as well as the hybridization results for each flowering period. The effect of wind is most evident in the 100 and $200 \mathrm{~m}$ arcs where hybridization 


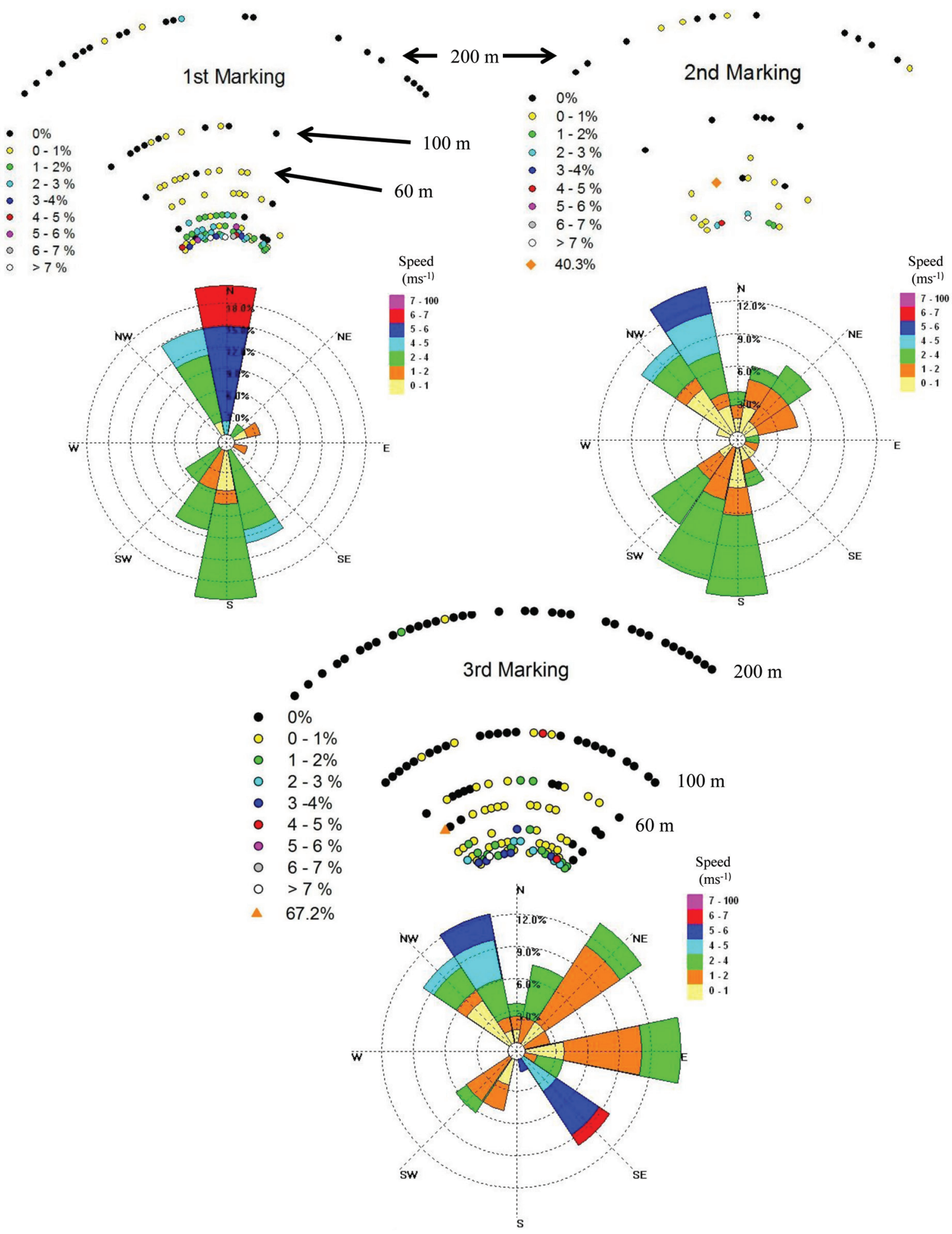

Figure 3. Wind trends and hybridization frequency results for the three flowering periods in 2008 occurring 31 August through 5 September (first), 3 through 11 September (second), and 9 through 17 September (third). Wind trends show wind blowing toward the direction specified.

was greater in the direction of greater wind proportion and speed.

Halsey et al. (2005) suggested that the size and relative pollen production of the pollen source are very important when evaluating pollen-mediated gene flow because it determines potential pollen density. Our 0.39-ha source population was large but not nearly as large as would be found in production-scale fields. Pollen density would be considerably greater in a larger field, which may result in a greater rate of hybridization. Furthermore, the likelihood 


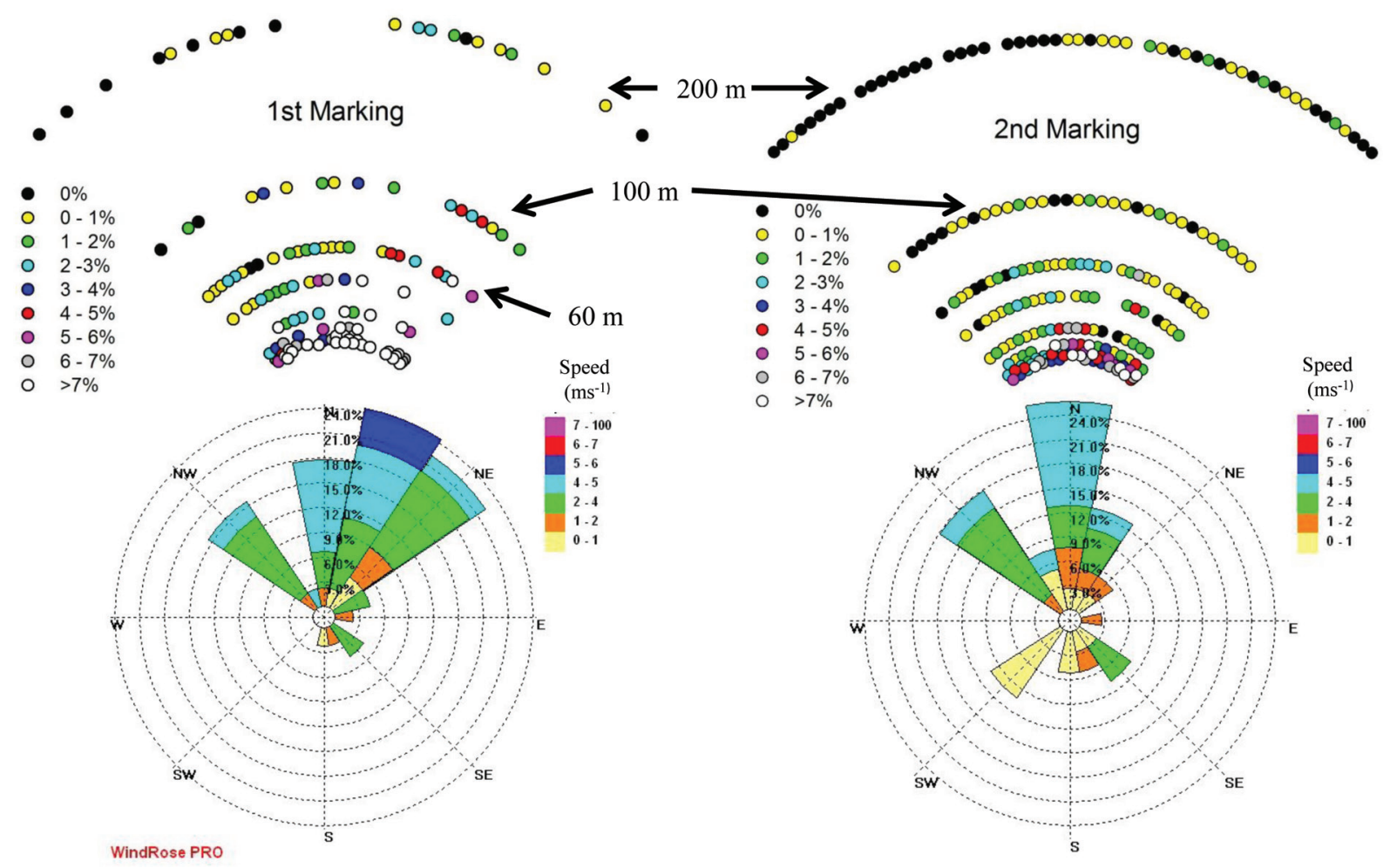

Figure 4. Wind trends and hybridization frequency results for the two flowering periods in 2009 occurring 12 through 16 August (first) and 14 through 18 August (second). Wind trends show wind blowing toward the direction specified.

Table 2. Analysis of variance and parameter estimates obtained by fitting frequency of hybridization to distance from the edge of the source population (dist) using the model: frequency of hybridization $=\alpha \exp (-\beta \times$ dist.).

\begin{tabular}{|c|c|c|c|c|c|c|c|c|c|c|}
\hline Year & Flowering period & Source & df & $\mathrm{MSE}^{\dagger}$ & $P>F$ & Coefficient & Estimate & SE & Confiden & interval \\
\hline \multirow[t]{2}{*}{2008} & 1 & Model & 2 & 0.0181 & $<0.0001$ & $\alpha$ & 0.0325 & 0.00268 & 0.0272 & 0.0378 \\
\hline & & Error & 117 & 0.00016 & & $\beta$ & 0.0732 & 0.0177 & 0.0383 & 0.1082 \\
\hline \multirow[t]{2}{*}{2008} & 2 & Model & 2 & 0.00419 & $<0.0001$ & $\alpha$ & 0.0863 & 0.0452 & -0.0053 & 0.1779 \\
\hline & & Error & 37 & 0.00016 & & $\beta$ & 0.7555 & 0.4853 & -0.2277 & 1.7388 \\
\hline \multirow[t]{2}{*}{2008} & 3 & Model & 2 & 0.00637 & $<0.0001$ & $\alpha$ & 0.0224 & 0.00245 & 0.0176 & 0.0270 \\
\hline & & Error & 145 & 0.00008 & & $\beta$ & 0.0585 & 0.0151 & 0.0287 & 0.0883 \\
\hline \multirow[t]{2}{*}{2009} & 2 & Model & 2 & 0.4189 & $<0.0001$ & $\alpha$ & 0.1591 & 0.00759 & 0.1441 & 0.1741 \\
\hline & & Error & 137 & 0.00132 & & $\beta$ & 0.0894 & 0.0133 & 0.0631 & 0.1158 \\
\hline \multirow[t]{2}{*}{2009} & 3 & Model & 2 & 0.114 & $<0.0001$ & $\alpha$ & 0.0797 & 0.00505 & 0.0697 & 0.0896 \\
\hline & & Error & 224 & 0.00054 & & $\beta$ & 0.0923 & 0.0141 & 0.0645 & 0.1202 \\
\hline
\end{tabular}

${ }^{\dagger} \mathrm{MSE}$, mean square error.

of hybridization will be most sensitive to large variations in source size and shape at greater distances from the source. In our experiment, hills $200 \mathrm{~m}$ from the source were less likely to be in the path of the pollen cloud for multiple wind directions than those within $20 \mathrm{~m}$ of the source. Including wind speed and direction in the analysis helps to correct for the effect of the smaller source population size by only including those shattercane hills in the direct path of the wind.

Our results indicate that when planted side by side, shattercane $\times$ sorghum hybridization is more similar to sorghum hybridization (10-15\%) than sudangrass hybridization (20\%) (Pedersen et al., 1998; Ellstrand and Foster, 1983; Schmidt and Bothma, 2006). The greater frequency of hybridization in 2009 might also be attributed to increased wind in 2009, suggesting that increased wind affects hybridization when planted side by side by disturbing and separating more pollen grains from the source plant, not just by carrying the pollen to a greater distance. Shattercane $\times$ sorghum hybridization can occur at distances of at least $200 \mathrm{~m}$ from the source, even with the limitation of a relatively small source size. Actual maximum distance for hybridization is determined by pollen density, pollen survival in the atmosphere, wind speed, and aerodynamic properties of the pollen grain (Aylor et al., 2003). Assuming no variation in sorghum pollen density, survival, or aerodynamic properties among marking periods, our results imply that wind speed and direction have an important influence on rate of hybridization. These results could be incorporated into 


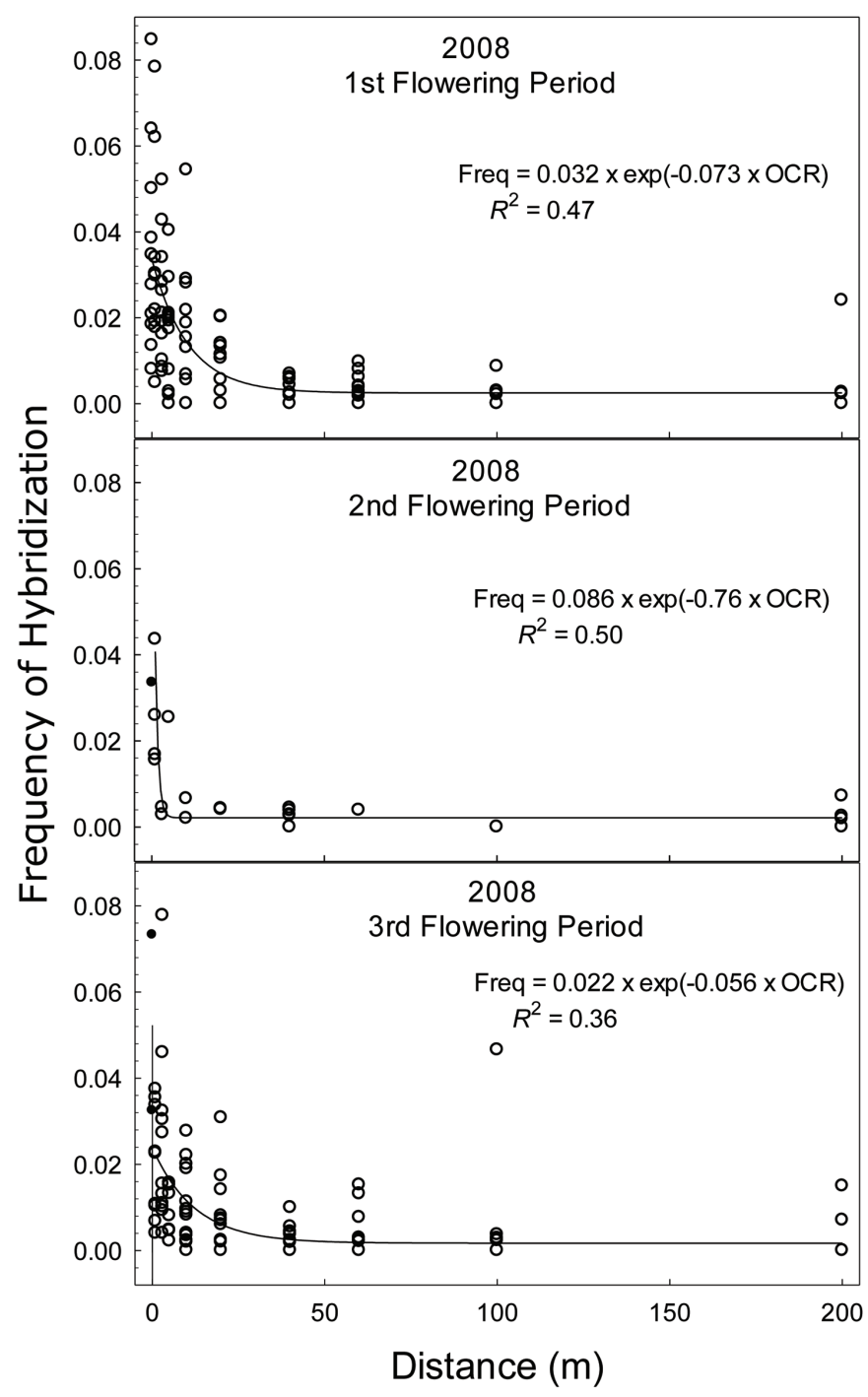

Figure 5. Hybridization frequency (Freq.) vs. distance for the three flowering periods in 2008. Note that there were often multiple observations at a given distance that had no hybridization. OCR, outcrossing rate.

more mechanistic models of pollen-mediated gene flow if additional information was available on pollen biology in the sorghum species.

Whereas this research provides insight into an important aspect of pollen-mediated gene flow, it does not provide an estimate of a population level introgression rate. The fitness of the subsequent hybrids as well as the amount of flowering synchrony will also affect gene introgression. While Sahoo et al. (2011) found the fitness of the $F_{1}$ hybrid to be similar to or greater than the shattercane parent, the fitness of subsequent generations has not been determined. Our results were obtained for sorghum and shattercane plants flowering in synchrony. It is not clear how frequently cultivated and weedy sorghums would flower in synchrony in natural populations under various sorghum management scenarios (e. g. different maturity groups, planting dates, tillage practices). Further research

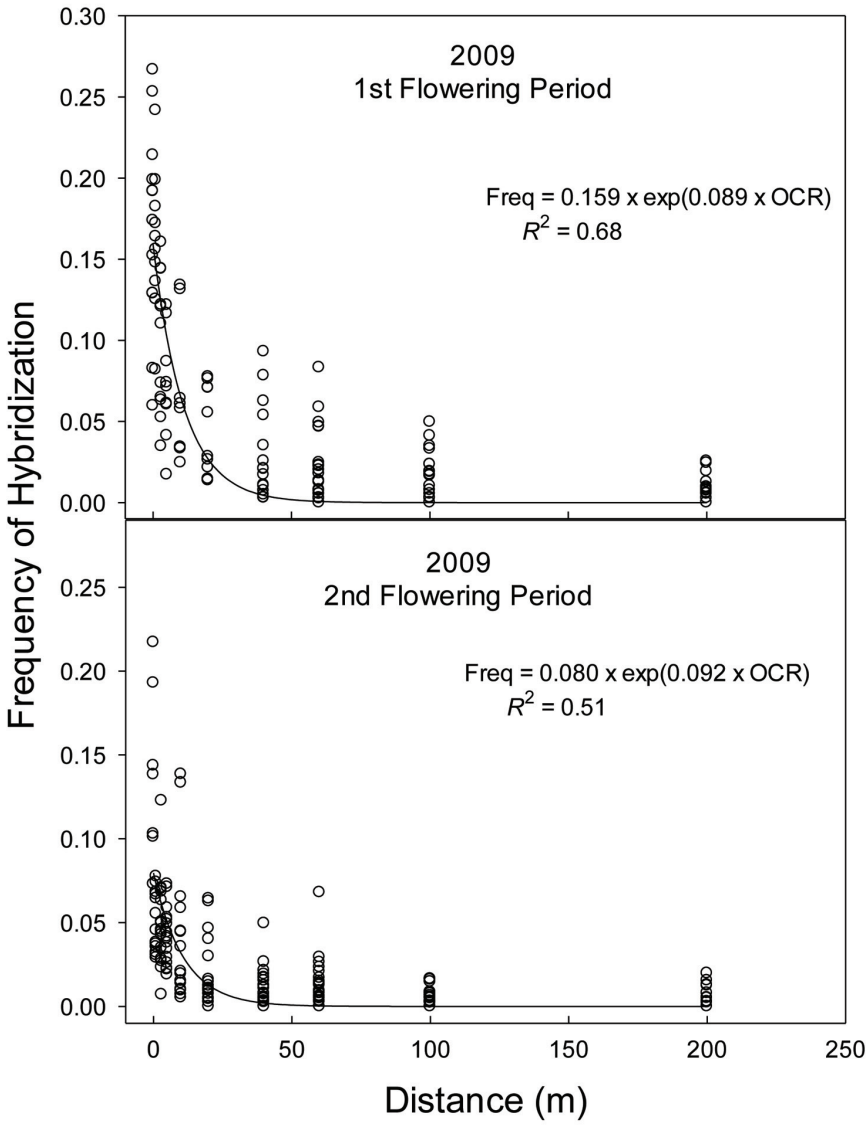

Figure 6. Hybridization frequency (Freq.) vs. distance for the two flowering periods in 2009. Again, there were often multiple observations at a given distance that had no hybridization. OCR, outcrossing rate.

Table 3. Analysis of variance tests for the effects of $\log$ (distance) and wind run on the frequency of hybridization for multiple flowering periods in 2008 and 2009. Values of $F$ and $P$ were obtained from the type III sums of squares.

\begin{tabular}{ccccc}
\hline Year & Flowering period & & $\boldsymbol{F}$ value & $\boldsymbol{P}$ value \\
\hline 2008 & 1 & Distance & 47.82 & $<0.0001$ \\
& & Wind run & 2.27 & 0.1346 \\
& & Distance $\times$ wind run & 14.03 & 0.0003 \\
& Distance & 3.4 & 0.736 \\
& Wind run & 13.95 & 0.0007 \\
& \multirow{2}{*}{3} & Distance $\times$ wind run & 5.12 & 0.0299 \\
& Distance & 1.3 & 0.2555 \\
& Wind run & 20.68 & $<0.0001$ \\
& \multirow{2}{*}{2009} & Distance $\times$ wind run & 8.11 & 0.005 \\
& Distance & 12.38 & 0.0006 \\
& Wind run & 144.53 & $<0.0001$ \\
& Distance $\times$ wind run & 29.25 & $<0.0001$ \\
& Distance & 8.31 & 0.0043 \\
& Wind run & 65.56 & $<0.0001$ \\
& Distance $\times$ wind run & 34.12 & $<0.0001$ \\
\hline
\end{tabular}

on the synchrony of flowering in weedy populations of shattercane and cultivated sorghum would also help to more accurately predict gene introduction rate from sorghum to shattercane populations. 


\section{References}

Andow, D.A., and C. Zwahlen. 2006. Assessing environmental risks of transgenic plants. Ecol. Lett. 9:196-214. doi:10.1111/ j.1461-0248.2005.00846.x

Arriola, P.E., and N.C. Ellstrand. 1997. Fitness of interspecific hybrids in the genus sorghum: Persistence of crop genes in wild populations. Ecol. Appl. 7:512-518. doi:10.1890/10510761(1997)007[0512:FOIHIT]2.0.CO;2

Aylor, D.E., N.P. Schultes, and E.J. Shields. 2003. An aerobiological framework for assessing cross-pollination in maize. Agric. For. Meteorol. 119:111-129. doi:10.1016/S0168-1923(03)00159-X

Baker, H.G. 1972. Migrations of weeds. In D.H. Valentine, editor, Taxonomy, phytogeography, and evolution. Academic Press, London, UK. p. 327-347.

Bannert, M., and P. Stamp. 2007. Cross-pollination of maize at long distance. Eur. J. Agron. 27:44-51.

Defelice, M.S. 2006. Shattercane, Sorghum bicolor (L.) Moench ssp. drummondii (Nees ex Steud.) de Wet ex Davidse-Black sheep of the family. Weed Technol. 20:1076-1083. doi:10.1614/ WT-06-051.1

Ellstrand, N.C., and K.W. Foster. 1983. Impact of population structure on the apparent outcrossing rate of grain sorghum (Sorghum bicolor). Theor. Appl. Genet. 66:323-327. doi:10.1007/BF00251167

Grand Challenges in Global Health. 2003. Nutritionally enhanced sorghum for the arid and semi arid tropical areas of Africa. Bill and Melinda Gates Foundation, Seattle, WA. http:// www.grandchallenges.org/ImproveNutrition/Challenges/ NutrientRichPlants/Pages/Sorghum.aspx (accessed 28 Mar. 2013).

Halsey, M.E., K.M. Remund, C.A. Davis, M. Qualls, P.J. Eppard, and S.A. Berberich. 2005. Isolation of maize from pollenmediated gene flow by time and distance. Crop Sci. 45:21722185. doi:10.2135/cropsci2003.0664

Hans, S.R., and W. Johnson. 2002. Influence of shattercane (Sorghum bicolor (L.) Moench.) interference on corn (Zea mays L.) yield and nitrogen accumulation. Weed Technol. 16:787-791. doi:10.1614/0890-037X(2002)016[0787:IOSSBL]2.0.CO;2

Hanson, B.D., C.A. Mallory-Smith, B. Shafii, D.C. Thill, and R.S. Semetra. 2005. Pollen-mediated gene flow from blue aleurone wheat to other wheat cultivars. Crop Sci. 45:16101617. doi:10.2135/cropsci2004.0443

Haygood, R., A.R. Ives, and D.A. Andow. 2003. Consequences of recurrent gene flow from crops to wild relatives. Proc. Biol. Sci. 270:1879-1886. doi:10.1098/rspb.2003.2426

Horak, M.J., and L.J. Moshier. 1994. Shattercane (Sorghum bicolor) biology and management. Rev. Weed Sci. 6:133-149.

ICRISAT. 2002. Sorghum, striga, and shattercane: Report of a biodiversity mission to Eritrea. International Crops Research Institute for the Semi-Arid Tropics (ICRISAT), Nairobi, Kenya.

Okubo, A., and S.A. Levin. 1989. A theoretical framework for data analysis of wind dispersal of seeds and pollen. Ecology 70:329-338. doi:10.2307/1937537

Pedersen, J.F., J.J. Toy, and B. Johnson. 1998. Natural outcrossing of sorghum and sudangrass in the central Great Plains. Crop Sci. 38:937-939. doi:10.2135/cropsci1998.0011183X003800040009x
Rieger, M.A., M. Lamond, C. Preston, S.B. Powles, and R.T. Roush. 2002. Pollen-mediated movement of herbicide resistance between commercial canola fields. Science 296(5577):2386-2388. doi:10.1126/science.1071682

Rupp, R.N., D.J. Meadows, D.W. Saunders, and W.J. Schumacher. 2009. Sulfonylurea and quizalofop tolerance traits in sorghum - New weed management tools for sorghum production. Proc. North Central Weed Sci. Soc. 64:126.

Sahoo, L., J.J. Schmidt, J.F. Pedersen, D.J. Lee, and J.L. Lindquist. 2011. Growth and fitness components of wild $\times$ cultivated Sorghum bicolor (Poaceae) hybrids in Nebraska. Am. J. Bot. 97:1610-1617. doi:10.3732/ajb.0900170

SAS Institute. 2009. The SAS system for Windows. Version 9.2. SAS Inst., Cary, NC.

Schmidt, M., and G. Bothma. 2006. Risk assessment for transgenic sorghum in Africa: Crop-to-crop gene flow in Sorghum bicolor (L.). Moench. Crop Sci. 46:790-798. doi:10.2135/ cropsci2005.06-0117

Song, Z.P., B. Lul, Y.G. Zhu, and J.K. Chen. 2003. Gene flow from cultivated the wild conditions species Oryza rufipogon under experimental field conditions. New Phytol. 157:657665. doi:10.1046/j.1469-8137.2003.00699.x

Spencer, L.J., and A.A. Snow. 2001 Fecundity of transgenic wildcrop hybrids of Cucurbita pepo (Cucurbitaceae): Implications for crop-to-wild gene flow. Heredity 86:694-702.

Tesso, T.T., K. Kershner, N. Ochanda, K. Al-Khatib, and M.R. Tuinstra. 2011. Registration of 34 sorghum germplasm lines resistant to acetolactate synthase-inhibitor herbicides. J. Plant Reg. 5:215-219. doi:10.3198/jpr2010.03.0184crg

Tuinstra, M.R., and K. Al-khatib. 2009. Acetolactate synthase herbicide resistant sorghum. European Patent EP2102349. Date issued: 23 September.

Tuinstra, M.R., and K. Al-khatib. 2010. Acetyl-coa carboxylase herbicide resistant sorghum. U.S. patent US 20100293628A1. Date issued: 18 November.

Tuinstra, M.R., and K. Al-khatib. 2011. Acetolactate synthase herbicide resistant sorghum. U.S. Patent application US 20110023161 A1.

Watrud, L.S., E.H. Lee, A. Fairbrother, C. Burdick, J.R. Reichman, M. Bollman, M. Storm, G. King, and P.K. Van de Water. 2004. Evidence for landscape-level, pollen-mediated geneflow from genetically modified creeping bentgrass with CP4 EPSPS as a marker. Proc. Natl. Acad. Sci. USA 101:14533-14538. doi:10.1073/pnas.0405154101

Wiersema, J.H., and J. Dahlberg. 2007. The nomenclature of Sorghum bicolor (L.) Moench (Gramineae). Taxonomy 56:941946. doi:10.2307/25065876

Wortman, C.S. R.B. Ferguson, G.W. Hergert, C.A. Shapiro, and T.M. Shaver. 2013. Nutrient management suggestions for grain sorghum. University of Nebraska-Lincoln extension publication. University of Nebraska, Lincoln, NE. http://www.ianrpubs.unl.edu/pages/publicationD. jsp?publicationId=671 (accessed 28 Mar. 2013). 